
A C G
Rec. Nat. Prod. 16:5 (2022) 409-416
publications

records of natural

products

\title{
A New Iridoid Glycoside from Wine-Processed Corni fructus
}

\author{
Qingmei Feng $\oplus^{1,2,3 \#}$, Hong Zhang $\oplus^{4 \#}$, Jing Wang $\oplus^{1,2,3}$, \\ Hongbin Li $\oplus^{1,2,3}$, Lingxia Zhang $\oplus^{1,2,3}$, Erping Xu $\oplus^{1,2,3}$, \\ Suiqing Chen $\oplus^{1,2,3}$, Zhimin Wang $\oplus^{1,2,3,5^{*}}$ and Liping Dai $\oplus^{1,2,3^{*}}$
}

\author{
${ }^{1}$ Henan University of Traditional Chinese Medicine, Zhengzhou, Henan 450046, P. R. China \\ ${ }^{2}$ Engineering Technology Research Center for Comprehensive Development and Utilization of \\ Authentic Medicinal Materials in Henan Province, Zhengzhou, Henan 450046, P. R. China \\ ${ }^{3}$ Zhengzhou Engineering Research Center for Food-Medicine Homologous substances from Henan \\ Province, Zhengzhou, Henan 450046, P. R. China \\ ${ }^{4}$ The Second Affiliated Hospital of Zhengzhou University, Zhengzhou, Henan 450046, P. R. China \\ ${ }^{5}$ Institute of Chinese Materia Medica, China Academy of Chinese Medical Sciences, Beijing 100700, \\ China
}

(Received October 14, 2021; Revised November 26, 2021; Accepted November 28, 2021)

\begin{abstract}
A new iridoid glycoside, cornusglucoside I (1), and a new natural product methyl 4-( $3^{\prime}, 4^{\prime}$ dihydroxyphenyl)-4-oxobutanoate (2), together with two known isolated compounds (3-4) were obtained from the $30 \%$ ethanol extract of the wine-processed Corni fructus. Their structures were clarified by spectroscopic analysis and literature data. The absolute configuration of $\mathbf{1}$ was elucidated by ECD calculation. By evaluating the NO production induced by LPS in RAW 264.7 cells to assess the anti-inflammatory activities of isolated compounds. Among the tested compounds, compounds $\mathbf{3}$ and $\mathbf{4}$ exhibited stronger anti-inflammatory activity than the positive drug dexamethasone $(6 \mu \mathrm{M})$, which may be potential anti-inflammatory drugs.
\end{abstract}

Keywords: Iridoid glycoside; wine-processed Corni fructus; anti- inflammatory activity. (C) 2021 ACG Publications. All rights reserved.

\section{Introduction}

Cornus officinalis is distributed in in Shaanxi, Gansu, Jiangxi, Henan and other provinces in China [1]. The fruits of $C$. officinalis have traditionally been used for nourishing the kidneys and liver for thousands of years in China, which was first recorded in Shen Nong's Materia Medica. [2]. Previous studies have shown the presence of iridoids, flavonoids, terpenoids, organic acid, polysaccharides and phenylpropanoids in C. officinalis [3-6]. Modern pharmacology studies revealed that the extracts and chemical components of $C$. officinalis have extensive biological activity, such as antiinflammatory, anti-oxidant, anti-diabetes, neuroprotective activities and cardiovascular system activities [7-10]. This traditional chinese medicine was obtained by steaming the clean pulp with

\footnotetext{
\# These authors contributed to this work equally.

*Corresponding author: E-Mail: zhmw123@163.com, liping_dai@ @actcm.edu.cn; Phone: +86-15040383307
} 
A new iridoid glycoside from wine-processed Corni fructus

yellow millet wine for 4-8 hours, which is the main form of traditional Chinese classical prescription in clinical medication. Modern studies indicated that wine-processed fruit of $C$. officinalis could help enhance the efficacy and reduce acidity compared with the untreated fruit. However, there were few studies on the wine-processed Corni fructus.

Modern pharmacology studies have shown that the mechanisms of $C$. officinalis in treating many diseases are related to its anti-inflammatory effects. Inflammation is an adaptive response to injury or harmful stimulation, it is closely related to the development of many diseases [11-13]. To characterize more potential therapeutic agents from the wine-processed Corni fructus to prevent inflammation, the chemical compositions were investigated. A new iridoid glycoside, namely cornusglucoside I (1), a new natural product methyl 4-(3',4'-dihydroxyphenyl)-4-oxobutanoate (2) and two known compounds (3-4) were obtained (Figure 1). And their potential anti-inflammatory activities were determined in our research.

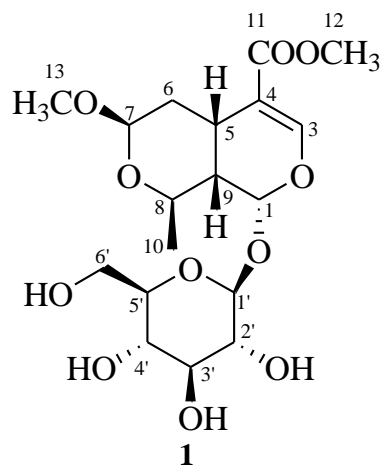<smiles>COC(=O)CCC(=O)c1ccc(O)c(O)c1</smiles><smiles>O=c1oc2c(O)c(O)ccc2c2cc(O)c(O)c(O)c12</smiles>

Figure 1. Chemical structures of $\mathbf{1}-\mathbf{4}$

\section{Materials and Methods}

\subsection{Apparatus and Reagents}

Rudolph AP-IV polarimeter (Rudolph, Hackettstown, NJ, USA); EVO 300 spectrometer; UPLCLTQ orbitrap XL Spectrometer; Nicolet IS 10 spectrometer (Thermo Fisher Scientific, Waltham, MA, USA). QBH LC-52 (Beijing Qingbohua Technology Co., Ltd., Beijing, China). Chirascan CD spectropolarimeter (Applied Photophysics, Leatherhead, Surrey, UK). Bruker Avance III 500-NMR instruments.

\subsection{Plant Material}

A voucher specimen (No. 2018-0413) of wine-processed Corni fructus was kept in the engineering technology research center for comprehensive development and utilization of authentic medicinal materials in Henan province, which were obtained from Zhengzhou Ruilong Co., Ltd. in Henan province, and were identified by Dr. Dai, Henan University of Chinese Medicine.

\subsection{Extraction and Isolation}

The dried materials $(50.0 \mathrm{~kg})$ were extracted with water $(500 \mathrm{~L} \times 2,2 \mathrm{~h})$ at $100^{\circ} \mathrm{C}$ to give a crude extract, which was separated by D101 macroporous resin with ethanol / water (0:100, 30:70, 70:30, v/v) to afford three parts (Fr. A-Fr. C). Fr. B (3.2 kg) was partitioned with ethyl acetate to afford an EtOAc soluble extract (Fr.B1, 409 g), which was separated into eight fractions (Fr. B1-1 Fr. B1-8) by use of silica gel column (200-300 mesh, $\mathrm{CHCl}_{3} / \mathrm{CH}_{3} \mathrm{OH}$ 1:0 to 0:1). Fr. B1-3 was divided by $\mathrm{C} 18$ column chromatography with $\mathrm{CH}_{3} \mathrm{OH} / \mathrm{H}_{2} \mathrm{O}$ to yield Fr. B1-1-1 $\sim$ Fr. B1-1-3. Fr. B1-1-3 was purified by HPLC with $15 \% \mathrm{CH}_{3} \mathrm{CN} / \mathrm{H}_{2} \mathrm{O}$ to yield compound $2\left(8 \mathrm{mg}, \mathrm{t}_{\mathrm{R}}=36 \mathrm{~min}\right), \mathbf{3}\left(7 \mathrm{mg}, \mathrm{t}_{\mathrm{R}}=20 \mathrm{~min}\right)$. Fr. 
B1-5 was isolated using $\mathrm{C} 18$ column chromatography with $\mathrm{CH}_{3} \mathrm{CN} / \mathrm{H}_{2} \mathrm{O}$ and HPLC with $15 \%$ $\mathrm{CH}_{3} \mathrm{CN} / \mathrm{H}_{2} \mathrm{O}$ to give $1\left(25 \mathrm{mg}, \mathrm{t}_{\mathrm{R}}=30 \mathrm{~min}\right), 4\left(9 \mathrm{mg}, \mathrm{t}_{\mathrm{R}}=18 \mathrm{~min}\right)$.

\subsection{Spectral Data}

Cornusglucoside I (1): White amorphous powder; $[\alpha]_{\mathrm{D}}^{25}-39.671\left(c 0.042, \mathrm{CH}_{3} \mathrm{OH}\right)$; IR $(\mathrm{KBr}) \lambda_{\max }$ : 3526, 3301, 2943, 2252, 1630, 1441, 1375, 1073, $1036 \mathrm{~cm}^{-1}$; UV $\left(\mathrm{CH}_{3} \mathrm{OH}\right) \lambda_{\max }(\log \varepsilon): 233$ (1.079) $\mathrm{nm}$; HR-ESI-MS at $\mathrm{m} / z$ 443.1528 [M + Na] ${ }^{+}$(calcd for $\left.\mathrm{C}_{18} \mathrm{H}_{28} \mathrm{O}_{11} \mathrm{Na}, 443.1529\right) ;{ }^{1} \mathrm{H}$ NMR $\left(\mathrm{CD}_{3} \mathrm{OD}\right.$, $500 \mathrm{MHz})$ and ${ }^{13} \mathrm{C}$ NMR $\left(125 \mathrm{MHz}, \mathrm{CD}_{3} \mathrm{OD}\right)$ data (Table 1).

Compound (2): Purple amorphous powder; IR (KBr) $\lambda_{\max }$ : 3350, 2956, 1730, 1670, 1597, 1440, 1291, $1167 \mathrm{~cm}^{-1}$; UV (MeOH) $\lambda_{\max }(\log \varepsilon): 205$ (1.237), 225 (1.176), 269 (0.822), 302 (0.524) nm; HR-ESIMS at $m / z 247.0576[\mathrm{M}+\mathrm{Na}]^{+}$(calcd for $\left.\mathrm{C}_{11} \mathrm{H}_{12} \mathrm{O}_{5} \mathrm{Na}, 247.0582\right) ;{ }^{1} \mathrm{H} \mathrm{NMR}\left(\mathrm{CD}_{3} \mathrm{OD}, 500 \mathrm{MHz}\right)$ and ${ }^{13} \mathrm{C}$ NMR (125 MHz, $\mathrm{CD}_{3} \mathrm{OD}$ ) data (Table 1).

Table 1. ${ }^{1} \mathrm{H}$ and ${ }^{13} \mathrm{C}$ NMR spectra data $(500 / 125 \mathrm{MHz})$ for 1 , cornusglucoside $\mathrm{H}$ and $(7 \beta)-7-O-$ methylmorroniside in $\mathrm{CD}_{3} \mathrm{OD}$.

\begin{tabular}{|c|c|c|c|c|c|c|}
\hline \multirow[b]{2}{*}{ Position } & \multicolumn{2}{|l|}{1} & \multicolumn{2}{|c|}{ Cornusglucoside $\mathbf{H}$} & \multicolumn{2}{|c|}{ (7ß)-7-O-methylmorroniside } \\
\hline & $\delta_{\mathrm{H}}$ & $\delta_{\mathrm{C}}$ & LIT $\delta_{\mathrm{H}}^{[15]}$ & LIT $\delta_{\mathrm{C}}^{[15]}$ & LIT $\delta_{\mathrm{H}}{ }^{[16]}$ & LIT $\delta_{C^{[16]}}^{[16]}$ \\
\hline 1 & $5.62(1 \mathrm{H}, \mathrm{d}, 3.5)$ & 95.6 & $5.63(1 \mathrm{H}, \mathrm{d}, 9.0)$ & 95.6 & $5.89(1 \mathrm{H}, \mathrm{d}, 9.1)$ & 95.5 \\
\hline 3 & $7.46(1 \mathrm{H}, \mathrm{s})$ & 153.7 & $7.46(1 \mathrm{H}, \mathrm{s})$ & 153.9 & $7.51(1 \mathrm{H}, \mathrm{s})$ & 154.1 \\
\hline 4 & & 110.6 & & 110.8 & & 111.7 \\
\hline 5 & $3.18(1 \mathrm{H}, \mathrm{m})$ & 25.5 & $2.84(1 \mathrm{H}, \mathrm{dt}, 13.2,4.2)$ & 25.8 & $3.05(1 \mathrm{H}, \mathrm{dt}, 12.9,4.6)$ & 28.5 \\
\hline 6 & $\begin{array}{l}1.64(1 \mathrm{H}, \mathrm{m}) \\
2.40(1 \mathrm{H}, \mathrm{m})\end{array}$ & 33.0 & $\begin{array}{l}1.13(1 \mathrm{H}, \mathrm{m}) \\
2.01(1 \mathrm{H}, \mathrm{m})\end{array}$ & 33.2 & $\begin{array}{c}1.52(1 \mathrm{H}, \mathrm{td}, 12.9,3.5) \\
1.92(1 \mathrm{H}, \mathrm{ddd}, 12.9 \\
4.6)\end{array}$ & 33.1 \\
\hline 7 & $4.38(1 \mathrm{H}, \mathrm{d}, 7.3)$ & 100.8 & $4.39(1 \mathrm{H}, \mathrm{dd}, 9.6,1.8)$ & 100.9 & $4.75(1 \mathrm{H}, \mathrm{brd}, 3.5)$ & 99.8 \\
\hline 8 & $3.75(1 \mathrm{H}, \mathrm{m})$ & 69.4 & $3.73(1 \mathrm{H}, \mathrm{m})$ & 69.6 & $4.29(1 \mathrm{H}, 6.9,2.1)$ & 66.1 \\
\hline 9 & $1.81(1 \mathrm{H}, \mathrm{m})$ & 43.1 & $1.80(1 \mathrm{H}, \mathrm{m})$ & 43.2 & $1.80(1 \mathrm{H}, \mathrm{m})$ & 40.5 \\
\hline 10 & $1.38(3 \mathrm{H}, \mathrm{d}, 6.3)$ & 20.4 & $1.38(3 \mathrm{H}, \mathrm{d}, 4.0)$ & 20.6 & $1.35(3 \mathrm{H}, \mathrm{d}, 6.9)$ & 18.9 \\
\hline 11 & & 168.7 & & 168.9 & & 168.5 \\
\hline 12 & $3.72(3 \mathrm{H}, \mathrm{s})$ & 51.7 & $3.71(3 \mathrm{H}, \mathrm{s})$ & 51.8 & $3.69(3 \mathrm{H}, \mathrm{s})$ & 51.4 \\
\hline 13 & $3.42(3 \mathrm{H}, \mathrm{s})$ & 56.2 & $3.42(3 \mathrm{H}, \mathrm{s})$ & 56.3 & $3.35(3 \mathrm{H}, \mathrm{s})$ & 54.7 \\
\hline $1^{\prime}$ & $4.66(1 \mathrm{H}, \mathrm{d}, 7.9)$ & 100.1 & $4.65(1 \mathrm{H}, \mathrm{d}, 5.4)$ & 100.3 & $4.79(1 \mathrm{H}, \mathrm{d}, 5.4)$ & 99.8 \\
\hline $2^{\prime}$ & $3.21(1 \mathrm{H}, \mathrm{m})$ & 74.6 & $3.19(1 \mathrm{H}, \mathrm{m})$ & 74.8 & $3.22(1 \mathrm{H}, \mathrm{dd}, 9.4,7.9)$ & 74.8 \\
\hline $3^{\prime}$ & $3.35(1 \mathrm{H}, \mathrm{m})$ & 78.3 & $3.35(1 \mathrm{H}, \mathrm{m})$ & 78.5 & $3.38(1 \mathrm{H}, \mathrm{t}, 9.4)$ & 78.0 \\
\hline $4^{\prime}$ & $3.27(1 \mathrm{H}, \mathrm{m})$ & 71.5 & $3.29(1 \mathrm{H}, \mathrm{m})$ & 71.7 & $3.28(1 \mathrm{H}, \mathrm{t}, 9.4)$ & 71.1 \\
\hline $5^{\prime}$ & $3.38(1 \mathrm{H}, \mathrm{m})$ & 77.9 & $3.37(1 \mathrm{H}, \mathrm{m})$ & 78.1 & $3.37(1 \mathrm{H}, \mathrm{m})$ & 78.5 \\
\hline $6^{\prime}$ & $\begin{array}{c}3.68(1 \mathrm{H}, \mathrm{dd}, \\
11.9,5.6) \\
3.91(1 \mathrm{H}, \mathrm{d}, 11.9)\end{array}$ & 62.7 & $\begin{array}{l}3.68(1 \mathrm{H}, \mathrm{m}) \\
3.90(1 \mathrm{H}, \mathrm{m})\end{array}$ & 62.9 & $\begin{array}{l}3.66(1 \mathrm{H}, \mathrm{dd}, 12.1,6.2) \\
3.89(1 \mathrm{H}, \mathrm{dd}, 12.1,6.2)\end{array}$ & 62.5 \\
\hline
\end{tabular}

Compound (3): White amorphous powder; ${ }^{1} \mathrm{H}$ NMR $\left(500 \mathrm{MHz}, \mathrm{CD}_{3} \mathrm{OD}\right) \delta_{\mathrm{H}}: 7.04(1 \mathrm{H}, \mathrm{d}, J=8.4 \mathrm{~Hz}$, H-3, 5), $6.71(1 \mathrm{H}, \mathrm{d}, J=8.4 \mathrm{~Hz}, \mathrm{H}-2,6), 4.31(1 \mathrm{H}, \mathrm{dd}, J=7.5,5.2 \mathrm{~Hz}, \mathrm{H}-8), 3.69(3 \mathrm{H}, \mathrm{s}, \mathrm{H}-10), 2.96$ $(1 \mathrm{H}, \mathrm{dd}, J=13.9,5.0 \mathrm{~Hz}, \mathrm{H}-7 \mathrm{~b}), 2.83(1 \mathrm{H}, \mathrm{dd}, J=13.9,7.5 \mathrm{~Hz}, \mathrm{H}-7 \mathrm{a}) .{ }^{13} \mathrm{C}$ NMR $\left(125 \mathrm{MHz}, \mathrm{CD}_{3} \mathrm{OD}\right)$ $\delta_{\mathrm{C}}: 175.9$ (C-9), 157.2 (C-4), 131.5 (C-3,5), 129.2 (C-1), 116.0 (C-2,6), 73.5 (C-8), 52.3 (C-10), 41.0 (C-7).

Compound (4): Colorless crystal; ${ }^{1} \mathrm{H}$ NMR $\left(500 \mathrm{MHz}, \mathrm{CD}_{3} \mathrm{OD}\right) \delta_{\mathrm{H}}: 8.45(1 \mathrm{H}, \mathrm{d}, J=9.0 \mathrm{~Hz}, \mathrm{H}-6$ '), $7.38(1 \mathrm{H}, \mathrm{s}, \mathrm{H}-5), 6.76\left(1 \mathrm{H}, \mathrm{d}, J=9.0 \mathrm{~Hz}, \mathrm{H}-5{ }^{\prime}\right) .{ }^{13} \mathrm{C}$ NMR $\left(125 \mathrm{MHz}, \mathrm{CD}_{3} \mathrm{OD}\right) \delta_{\mathrm{C}}: 163.8(\mathrm{C}-7), 146.8$ (C-4'), 146.5 (C-4), 144.0 (C-2), 142.0 (C-3), 141.0 (C-2'), 133.3 (C-3'), 119.1 (C-6'), 118.5 (C-1), $112.9(\mathrm{C}-1$ '), $112.4(\mathrm{C}-5), 112.0(\mathrm{C}-6), 108.1(\mathrm{C}-5)$. 
A new iridoid glycoside from wine-processed Corni fructus

\subsection{Computational Details}

The ECD spectra of compound $\mathbf{1}$ was measured by Applied Photophysics Chirascan CD spectropolarimeter and the energy-minimized conformers was obtained via the Molecular Mechanics field in Spartan 14, and the geometries were further optimized using integral equation formal variable polarization continuum model, without vibration imaginary frequency [14]. The time-dependent density functional theory (TDDFT) method is used to perform the theoretical calculation of the ECD spectrum of the main conformer of $\mathbf{1}$ at the level of RB3LYP/6-31G $(\mathrm{d}, \mathrm{p})$. Gaussian 6.1 was used to calculate the ECD curve. The result of $\mathbf{1}$ was drawn by SpecDic software and OriginPro 8.

\subsection{Determination of RAW 264.7 cells viability in vitro}

RAW264.7 cells were incubated in a humidified $5 \% \mathrm{CO}_{2}$ atmosphere at $37^{\circ} \mathrm{C}$ in 96 -well plates $(8$ $\times 10^{4}$ cells/well $)$ and treated with different concentrations of isolated compounds $(200,100,50,25$, $12.5,6.25,0 \mu \mathrm{M})$. After $24 \mathrm{~h}$, cell viability was measured by CCK- 8 method.

\subsection{Anti-inflammatory activity in vitro}

The Griess reaction is used to measure the accumulation of nitrite in the medium. RAW264.7 cells $\left(2.5 \times 10^{5}\right.$ cells/well) were placed on a 96-well microtiter plate and treated with each compound in the presence of LPS $(1 \mu \mathrm{g} / \mathrm{mL})$ for 24 hours. Mixing medium supernatant $(50 \mu \mathrm{l})$ with Griess reagent $(100 \mu \mathrm{l})$ (part I: $1 \%$ sulfonamide; part II: $0.1 \%$ naphthylethylene diamide dihydrochloride and $2 \%$ phosphoric acid) at $37^{\circ} \mathrm{C}$. After 10 minutes, the absorbance was measured at $540 \mathrm{~nm}$.

\section{Results and Discussion}

\subsection{Structure Elucidation}

Cornusglucoside I (1) was isolated as a white amorphous powder. The infrared spectrum revealed the hydroxyl $\left(3526 \mathrm{~cm}^{-1}\right)$ and carbonyl $\left(1630 \mathrm{~cm}^{-1}\right)$ groups of $\mathbf{1}$. UV spectral data showed three absorption peaks at $233 \mathrm{~nm}$. A HREIMS $[\mathrm{M}+\mathrm{Na}]^{+}$peak at $m / z 443.1528$ indicated that the molecular formula of compound 1 was $\mathrm{C}_{18} \mathrm{H}_{28} \mathrm{O}_{11}$ with 5 sites of unsaturation. The ${ }^{1} \mathrm{H}$ NMR and ${ }^{13} \mathrm{C}$ NMR data displayed characteristic resonances for one methyl $\left[\delta_{\mathrm{H}} 1.38(3 \mathrm{H}, \mathrm{d}, J=6.3 \mathrm{~Hz}, \mathrm{H}-10) ; \delta_{\mathrm{C}} 20.4(\mathrm{C}-10)\right]$, two methylene $\left[\delta_{\mathrm{H}} 1.64(1 \mathrm{H}, \mathrm{m}, \mathrm{H}-6 \mathrm{a}), 2.40(1 \mathrm{H}, \mathrm{m}, \mathrm{H}-6 \mathrm{~b}), 3.68\left(1 \mathrm{H}, \mathrm{dd}, J=11.9,5.6 \mathrm{~Hz}, \mathrm{H}-6{ }^{\prime} \mathrm{a}\right), 3.91\right.$ $\left(1 \mathrm{H}, \mathrm{d}, J=11.9 \mathrm{~Hz}, \mathrm{H}-6^{\prime} \mathrm{b}\right) ; \delta_{\mathrm{C}} 33.60(\mathrm{C}-6), 62.7\left(\mathrm{C}-6^{\prime}\right)$, respectively], three methines $\left[\delta_{\mathrm{H}} 3.18(1 \mathrm{H}, \mathrm{m}\right.$, H-5), $1.81(1 \mathrm{H}, \mathrm{m}, \mathrm{H}-9), 3.75(1 \mathrm{H}, \mathrm{m}, \mathrm{H}-8) ; \delta_{\mathrm{C}} 25.5$ (C-5), 43.1 (C-9), 69.4 (C-8), respectively], two methoxy groups $\left[\delta_{\mathrm{H}} 3.42(3 \mathrm{H}, \mathrm{s}, \mathrm{H}-13), 3.72(3 \mathrm{H}, \mathrm{s}, \mathrm{H}-12) ; \delta_{\mathrm{C}} 56.2(\mathrm{C}-13), 51.7(\mathrm{C}-12)\right.$, respectively], two acetal signals $\left[\delta_{\mathrm{H}} 5.62(1 \mathrm{H}, \mathrm{d}, J=3.5 \mathrm{~Hz}, \mathrm{H}-1), 4.38(1 \mathrm{H}, \mathrm{d}, J=7.3 \mathrm{~Hz}, \mathrm{H}-7) ; \delta_{\mathrm{C}} 95.6(\mathrm{C}-1), 100.8\right.$ $(\mathrm{C}-7)$, respectively], one trisubstituted double bonds $\left[\delta_{\mathrm{H}} 7.46(1 \mathrm{H}\right.$, br.s, $\mathrm{H}-3) ; \delta_{\mathrm{C}} 157.3(\mathrm{C}-3), 110.6(\mathrm{C}-$ $4)]$, one ester carbonyl carbon $\left[\delta_{\mathrm{C}} 168.7(\mathrm{C}-11)\right]$. The NMR spectrum showed one set of glucose characteristic signals $\left[\delta_{\mathrm{H}} 3.21 \sim 4.66 ; \delta_{\mathrm{C}} 100.1\left(\mathrm{C}-1^{\prime}\right), 74.6\left(\mathrm{C}-2^{\prime}\right), 78.31\left(\mathrm{C}-3^{\prime}\right), 71.51\left(\mathrm{C}-4^{\prime}\right), 77.9(\mathrm{C}-\right.$ $\left.5^{\prime}\right), 62.7\left(\mathrm{C}-6^{\prime}\right)$ ] (Table 1). The coupling constant $(J=7.9 \mathrm{~Hz})$ of the anomeric proton at $\delta_{\mathrm{H}} 4.66$ indicated that the glucopyranosyl moiety was in $\beta$ configuration. These spectroscopic data of 1 was similar to cornusglucoside $\mathrm{H}$ and $(7 \beta)-7-O$-methylmorroniside, which indicated that $\mathbf{1}$ may be an iridoid glycoside [15, 16]. The 2D structure of 1 was verified by the $\mathrm{HMBC}$ correlations between $\mathrm{H}-1$ and C-5/C-8/C-1'/C-3, H-3 and C-5/C-1/C-4/C-11, H-5 and C-6/C-9/C-8/C-4/C-3, H-7 and C-6/C-5/C8/C-13, H-10 and C-9/C-8. Furthermore, according to the correlation between $\mathrm{H}-1$ and $\mathrm{C}-1$ ' in the HMBC spectrum, it is judged that the $\mathrm{C}-1$ ' is connected to $\mathrm{C}-1$ position, and the planar structure is determined to be the same as cornusglucoside $\mathrm{H}$ and $(7 \beta)-7-O$-methylmorroniside $[15,16]$. The relative configuration of $\mathbf{1}$ was established by a NOESY experiment (Fig. 2). The NOE correlations from $\mathrm{H}-9$ to $\mathrm{H}-1 / \mathrm{H}-5 / \mathrm{H}_{3}-10$, and from $\mathrm{H}_{3}-13$ to $\mathrm{H}_{3}-10$ indicated their cofacial orientation, and $\mathrm{H}-7, \mathrm{H}-$ 8 were on the other side. And the optical rotation value of 1 was $[\alpha]_{\mathrm{D}}^{25}-39.671\left(c 0.042, \mathrm{CH}_{3} \mathrm{OH}\right)$, 
which was different from that of cornusglucoside $\mathrm{H}[\alpha]_{\mathrm{D}}^{20}-165.45\left(c 0.04, \mathrm{CH}_{3} \mathrm{OH}\right)$ and $(7 \beta)-7-O$ methylmorroniside $[\alpha]_{\mathrm{D}}^{20}-125\left(c 0.083, \mathrm{CH}_{3} \mathrm{OH}\right)[15,16]$. The correlations of NOESY spectrum confirmed that its relative configuration, which is different from that of cornusglucoside $\mathrm{H}$ and $(7 \beta)-7$ $O$-methylmorroniside.

In order to further verify the absolute configuration of $\beta$-glucose, acid hydrolysis was carried out according to the method of literature, and the optical rotation value of $\beta$-glucose was $[\alpha]_{\mathrm{D}}^{25}=+11(c$ $0.07, \mathrm{MeOH})$, which determined the structure of $\beta$-D-glucose.

The calculated ECD spectrum of 1 showed a positive Cotton effect at $250 \mathrm{~nm}$ and a negative Cotton effect at $225 \mathrm{~nm}$ (Fig. 3), which matched well with that of the experimental one. Thus, the absolute configuration of 1 was $1 R, 5 S, 7 R, 8 R, 9 S$.
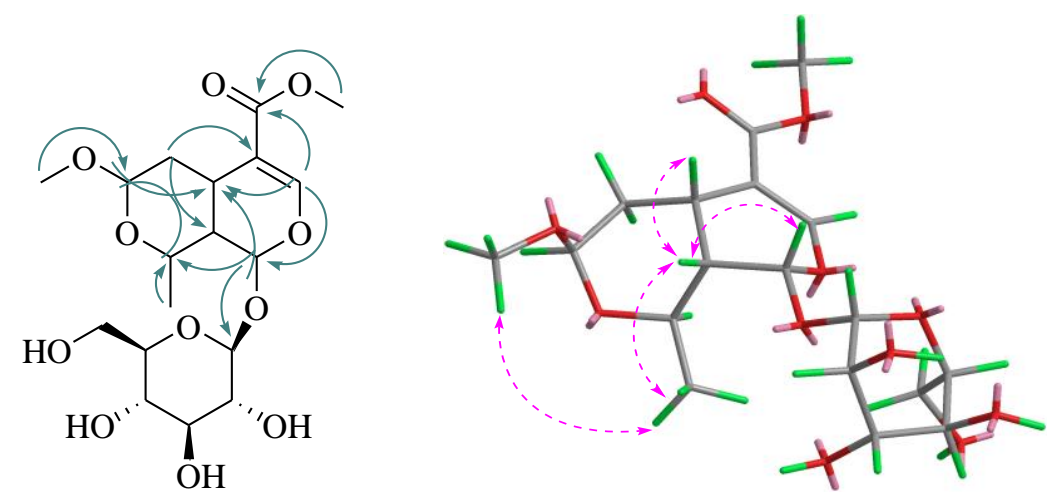

Figure 2. HMBC $(\curvearrowright)$ and $\operatorname{NOESY}(\cdots)$ correlations of compound $\mathbf{1}$.

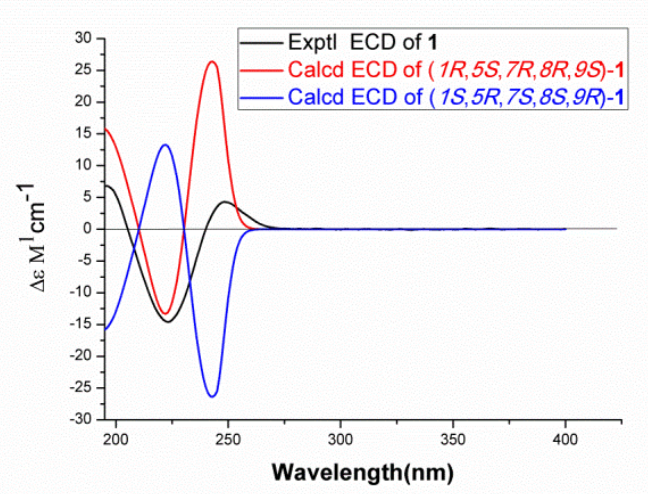

Figure 3. Comparison of the experimental and calculated ECD spectra of compound $\mathbf{1}$

Compound 2 was obtained as purple amorphous powder and gave a $[\mathrm{M}+\mathrm{Na}]^{+}$peak at $\mathrm{m} / \mathrm{z}$ 247.0576 in the HRESIMS for a molecular formula of $\mathrm{C}_{11} \mathrm{H}_{12} \mathrm{O}_{5} \mathrm{Na}$, requiring 6 sites of unsaturation. The IR spectrum $\left(3350,1730 \mathrm{~cm}^{-1}\right)$ showed the presence of hydroxyl and carbonyl groups. UV spectral data showed three absorption peaks at 205, 225, 269, $302 \mathrm{~nm}$. The ${ }^{1} \mathrm{H}$ NMR data (Table 1) displayed characteristic resonances for one ABX trisubstituted phenyl signals $\left[\delta_{\mathrm{H}} 6.83(1 \mathrm{H}, \mathrm{d}, J=8.0\right.$ $\left.\left.\mathrm{Hz}, \mathrm{H}-5^{\prime}\right), 7.42\left(1 \mathrm{H}, \mathrm{s}, \mathrm{H}-2^{\prime}\right), 7.45\left(1 \mathrm{H}, \mathrm{d}, J=8.0 \mathrm{~Hz}, \mathrm{H}-6^{\prime}\right)\right]$, two methylene [ $\delta_{\mathrm{H}} 2.67(2 \mathrm{H}, \mathrm{t}, J=6.2$ $\mathrm{Hz}, \mathrm{H}-2), 3.25(2 \mathrm{H}, \mathrm{t}, J=6.2 \mathrm{~Hz}, \mathrm{H}-3)]$, one methoxy signal $\left[\delta_{\mathrm{H}} 3.67(3 \mathrm{H}, \mathrm{s}, \mathrm{H}-5)\right]$. The ${ }^{13} \mathrm{C}$ NMR spectrum showed one set of phenyl signals $\left[\delta_{\mathrm{C}} 115.8\left(\mathrm{C}-2^{\prime}\right), 115.9\left(\mathrm{C}-5^{\prime}\right), 122.9\left(\mathrm{C}-6^{\prime}\right), 130.2\left(\mathrm{C}-1^{\prime}\right)\right.$, $\left.146.5\left(\mathrm{C}-3^{\prime}\right), 152.3\left(\mathrm{C}-4^{\prime}\right)\right]$, one ester carbonyl carbon $\left[\delta_{\mathrm{C}} 175.4(\mathrm{C}-1)\right]$, one ketocarbonyl carbon $\left[\delta_{\mathrm{C}}\right.$ $199.1(\mathrm{C}-4)]$, one methoxy carbon $\left[\delta_{\mathrm{C}} 52.2(\mathrm{C}-5)\right]$ and other two sp ${ }^{3}$ carbon $\left[\delta_{\mathrm{C}} 29.1(\mathrm{C}-2), 33.8(\mathrm{C}-3)\right]$. The HMBC correlations from $\mathrm{H}-2$ to $\mathrm{C}-1 / \mathrm{C}-3 / \mathrm{C}-4, \mathrm{H}-3$ and $\mathrm{C}-1 / \mathrm{C}-2 / \mathrm{C}-4, \mathrm{H}-5$ and $\mathrm{C}-1, \mathrm{H}-2$ ' and $\mathrm{C}-$ 4/C-4'/C-6', H-5'to C-1'/C-3', and H-6' to C-4/C-2'/C-4' (Fig. 4). The ${ }^{1} \mathrm{H}$ and ${ }^{13} \mathrm{C}$ NMR spectroscopic data of 2 were comparable with those of methyl 4-(3',4'-dihydroxyphenyl)-4-oxobutanoate. Analysis of the NMR data as well as the HMBC correlations clarified the elucidation for the structure of $\mathbf{2}$, 
A new iridoid glycoside from wine-processed Corni fructus

which is same as a synthetic compound reported in the literature [17]. Therefore, we determined that compound $\mathbf{2}$ is a new natural product, namely methyl 4-(3',4'-dihydroxyphenyl)-4-oxobutanoate.

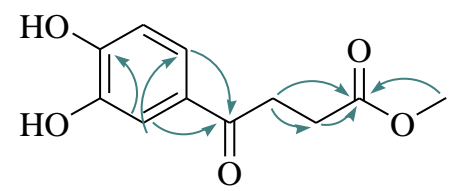

Figure 4. HMBC correlations ( $\frown$ ) of compound 2

Compound 3 was obtained as White amorphous powder. The ${ }^{1} \mathrm{H}$ NMR and ${ }^{13} \mathrm{C}$ NMR data displayed characteristic resonances for $p$-disubstituted phenyl signals $\left[\delta_{\mathrm{H}} 7.04(1 \mathrm{H}, \mathrm{d}, J=8.4 \mathrm{~Hz}, \mathrm{H}-3\right.$, 5), $6.71(1 \mathrm{H}, \mathrm{d}, J=8.4 \mathrm{~Hz}, \mathrm{H}-2,6) ; \delta_{\mathrm{C}} 129.2(\mathrm{C}-1), 116.0(\mathrm{C}-2,6), 131.5(\mathrm{C}-3,5), 157.2(\mathrm{C}-4)$, respectively], one oxygenated methine $\left[\delta_{\mathrm{H}} 4.31(1 \mathrm{H}, \mathrm{dd}, J=7.5,5.2 \mathrm{~Hz}, \mathrm{H}-8) ; \delta_{\mathrm{C}} 73.5(\mathrm{C}-8)\right]$, one one methoxy signal $\left[\delta_{\mathrm{H}} 3.69(3 \mathrm{H}, \mathrm{s}, \mathrm{H}-10) ; \delta_{\mathrm{C}} 52.3(\mathrm{C}-10)\right]$, one methylene $\left[\delta_{\mathrm{H}} 2.96(1 \mathrm{H}, \mathrm{dd}, J=13.9,5.0\right.$ $\left.\mathrm{Hz}, \mathrm{H}-7 \mathrm{~b}), 2.83(1 \mathrm{H}, \mathrm{dd}, J=13.9,7.5 \mathrm{~Hz}, \mathrm{H}-7 \mathrm{a}) ; \delta_{\mathrm{C}} 41.0(\mathrm{C}-7)\right]$, and one ester carbonyl carbon $\left[\delta_{\mathrm{C}}\right.$ 175.9 (C-9)]. Compounds 3 was determined as methyl $p$-hydroxyphenyllactate based on the ${ }^{1} \mathrm{H}$ and ${ }^{13} \mathrm{C}$ NMR data [18].

Compound 4 was obtained as Colorless crystal. The ${ }^{1} \mathrm{H}$ NMR and ${ }^{13} \mathrm{C}$ NMR date displayed characteristic resonances for two phenyl signals $\left[\delta_{\mathrm{H}} 7.38(1 \mathrm{H}, \mathrm{s}, \mathrm{H}-5), 6.76\left(1 \mathrm{H}, \mathrm{d}, J=9.0 \mathrm{~Hz}, \mathrm{H}-5^{\prime}\right)\right.$, $8.45\left(1 \mathrm{H}, \mathrm{d}, J=9.0 \mathrm{~Hz}, \mathrm{H}-6^{\prime}\right) ; \delta_{\mathrm{C}}: 118.5$ (C-1), 144.0 (C-2), 142.0 (C-3), 146.5 (C-4), 108.1 (C-5), 112.0 (C-6), 112.9 (C-1'), 141.0 (C-2'), 133.3 (C-3'), 146.8 (C-4'), 112.4 (C-5'), 119.1 (C-6')], and one ester carbonyl carbon $\left[\begin{array}{lll}\delta_{\mathrm{C}} & 163.8(\mathrm{C}-7)\end{array}\right]$. Compounds 4 was determined as $3,4,8,9,10-$ Pentahydroxydibenzo[b,d]pyran-6-one based on the ${ }^{1} \mathrm{H}$ and ${ }^{13} \mathrm{C}$ NMR data [19].

\subsection{Biological Activities}

RAW264.7 viability: The in vitro cytotoxicity of compounds (1-4) on RAW264.7 cells were evaluated by CCK-8 assay. As shown in Fig. S18. Compound $\mathbf{1}$ showed no cytotoxic activity toward RAW264.7. Compound $\mathbf{2}$ showed very weak cytotoxic activity that $\mathrm{IC}_{50}$ value was greater than 200 $\mu \mathrm{M}$. Compound $\mathbf{3}$ and $\mathbf{4}$ have different levels of cytotoxic activity toward RAW264.7 with $\mathrm{IC}_{50}$ values of $17.2 \mu \mathrm{M}$ and $13.5 \mu \mathrm{M}$. According to the result of cells viability assay, we selected the appropriate dosage concentration that make the cell survival rate greater than $90 \%$, and conduct the antiinflammatory assay.

The anti-inflammatory activities in vitro of the compound $\mathbf{1}(6.25,50,200 \mu \mathrm{M})$ and compounds 2, 3, $4(1.5,3,6 \mu \mathrm{M})$ were assayed by assessing LPS-induced NO production. Significantly, compounds 3 and $4(1.5,3,6 \mu \mathrm{M})$ have the better anti-inflammatory activity than positive control dexamethasone $(6 \mu \mathrm{M})$.
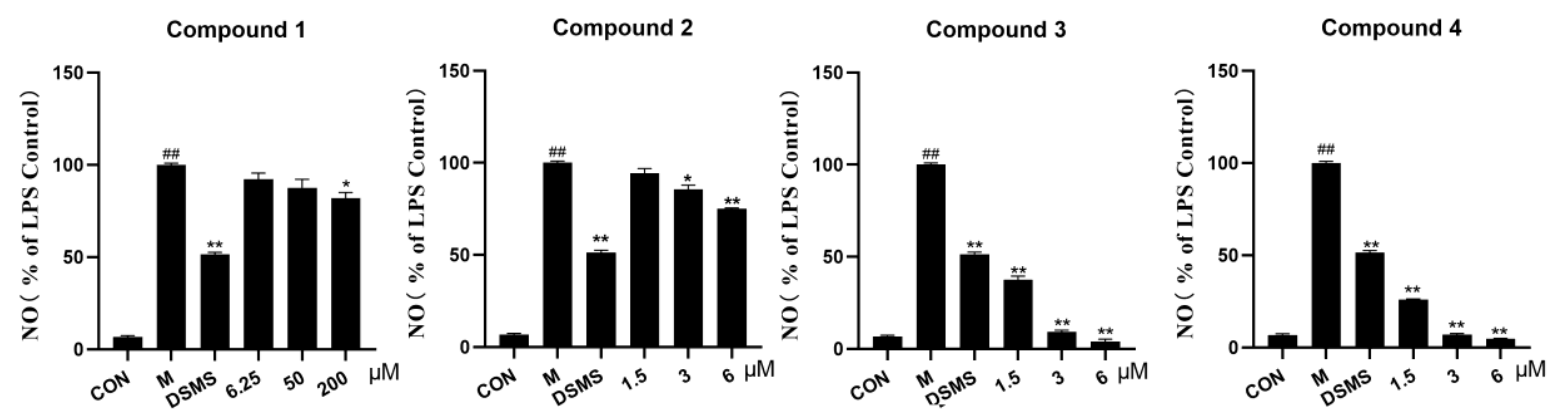

Figure 5. The effect of compounds 1-4 on the level of NO in RAW264.7 cells induced by LPS $\left(\mathrm{x} \pm \mathrm{s}, \mathrm{n}=3\right.$ ). Positive drug: dexamethasone (DSMS); Compare with control ${ }^{\#} P<0.001$; Compare with model ${ }^{*} P<0.05,{ }^{* *} P<0.001$. 


\section{Conclusion}

In present study, systematic chemical research was carried out and resulted in the separation of a new iridoid glycoside (1), together with a new natural product (2) and two known compounds (3-4) from the ethyl acetate layer of wine-processed Corni fructus. The literature showed that iridoids and organic acids have anti-inflammatory activity. All compounds have been subjected to anti-inflammatory experiments in vitro. As the results shown, $\mathbf{1}$ and $\mathbf{2}$ showed very weak anti-inflammatory activity, and

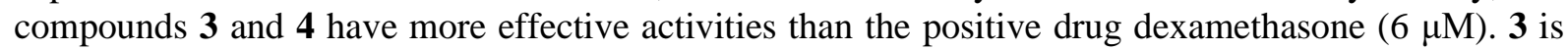
an inhibitor of cell growth and proliferation and an endogenous ligand for nuclear type-II binding sites [20]. There are few reports on its anti-inflammatory activity in the literature. Compound $\mathbf{4}$ has potential anti-inflammatory activity as an ellagic compound [21]. This research has enriched the information on the chemical composition of wine-processed Corni fructus, which is conducive to a better understanding of the medicinal characteristics of this traditional Chinese medicine.

\section{Acknowledgments}

This work was supported in part by the National Key Research and Development Program of China (No. 2017YFC1701904), part of measuring the NMR, IR, UV, and MS spectra was supported by the Department of Instrumental Analysis, Henan University of Traditional Chinese Medicine.

\section{Supporting Information}

Supporting information accompanies this paper on http://www.acgpubs.org/journal/records-of$\underline{\text { natural-products }}$

\section{ORCID}

Qingmei Feng: 0000-0001-9278-3513

Hong Zhang: 0000-0002-0565-2230

Jing Wang: 0000-0002-9049-1880

Hongbin Li: 0000-0002-3444-6532

Lingxia Zhang: 0000-0002-5562-6735

Erping Xu: 0000-0002-6610-1387

Suiqing Chen: 0000-0003-0449-168X

Zhimin Wang: 0000-0003-4770-3814

Liping Dai: 0000-0002-1910-7591

\section{References}

[1] Chinese Pharmacopoeia Committee (2020). Pharmacopoeia of People's Republic of China, Part 1. Bei Jing: The Medicine Science and Technology Press of China. p. 74.

[2] J. He, X. S. Ye, X. X. Wang, Y. N. Yang, P. C. Zhang, B. Z. Ma, W. K. Zhang and J. K. Xu, (2017). Four new iridoid glucosides containing the furan ring from the fruit of Cornus officinalis. Fitoterapia, 120, 136141.

[3] X. Y. Xie, R. Wang, Y. P. Shi (2012). Chemical constituents from the fruits of Cornus officinalis, Biochem. System. Ecol. 45, 120-123.

[4] X. S. Ye, J. He, Y. C. Cheng, L. Zhang, H. Y. Qiao, X. G. Pan, J. Zhang, S. N. Liu, W. K. Zhang and J. K. $\mathrm{Xu}$ (2017). Cornusides A-O, bioactive iridoid glucoside dimers from the fruit of Cornus officinalis, J. Nat. Prod. 80, 3103-3111.

[5] L. L. Ji, X. Wang, J. J. Li, X. J. Zhong, B. Zhang, J. Juan and X. Y. Shang (2019). New iridoid derivatives from the fruits of Cornus officinalis and their neuroprotective activities, Molecules 24, 625.

[6] R. Q. Yao, L. Zhang, W. Wang and L. Li (2009). Cornel iridoid glycoside promotes neurogenesis and angiogenesis and improves neurological function after focal cerebral ischemia in rats, Brain Res. Bull. 79, 69-76. 
A new iridoid glycoside from wine-processed Corni fructus

[7] X. Ding, M. Y. Wang, Y. U. Zong-Liang, H. U. Wei and B. C. Cai (2008). Studies on separation, appraisal and the biological activity of 5-hmf in cornus officinalis, China J. Chines. Mater. Med. 33(4), 392

[8] Y. Wang, S. Wei, K. Wang, Z. Wang and S. Wang (2020). Evaluation of biosynthesis parameters, stability and biological activities of silver nanoparticles synthesized by cornus officinalis extract under $365 \mathrm{~nm}$ uv radiation, $R S C A d v$. 10(45), 27173-27182.

[9] S. H. Kwon, H. S. Yang, J. Y. Kim, K. W. Park and K. I. Seo (2009). Biological activities of ethanol extract from corni fructus, J. Korean Soc. Food Sci. Nutr. 38(3), 287-291.

[10] Lee, D. S. Jang, N. H. Kim, Y. M. Lee, J. Kim and J. S. Kim. (2011). Galloyl glucoses from the seeds of Cornus officinalis with inhibitory activity against protein glycation, aldose reductase, and cataractogenesis ex vivo, Biol. Pharmaceut. Bull. 34(3), 443-446.

[11] K Imanak-Yoshida (2020). Inflammation in myocardial disease: from myocarditis to dilated cardiomyopathy, Pathol. Int. 70(1), 1-11.

[12] A. Nasef and S. Mehta (2020). Role of inflammation in pathophysiology of colonic disease: an update, Int. J. Molecul. Sci. 21(13), 4748-4769.

[13] Tripathi, S. Kant, S. Pandey, N. Z. Ehtesham (2020). Resistin in metabolism, inflammation, and disease, FEBS J. 287(15), 3141-3149.

[14] G. Bringmann, T. Bruhn, K. Maksimenka and Y. Hemberger (2009). The assignment of absolute stereostructures through quantum chemical circular dichroism calculations, Eur. J. Org. Chem. 40, 27172727.

[15] X. S. Ye (2017). Study on the chemical constituents and biological activity of the fruit of Cornus officinalis [D]. Beijing University of Chinese Medicine.

[16] J. F. Hu, C. M. Starks, R. B. Williams, S. M. Rice, V. L. Norman, K. M. Olson, G. W. Hough, M. G. Goering, M. O. Johnson and G. R. Eldridge (2009). Secoiridoid glycosides from the pitcher plant Sarracenia alata, Helv. Chim. Acta, 92, 273-280.

[17] W. M. Zhao, H. Y. Zhang, J. J Qin, L. Wu, H. M. Wang, H. X. Feng, R. J. Zhang, W. Wang, X. C. Shao, L. $X$. Tao and X. Ding (2019). Class of phenylcarboxylic acid derivatives, preparation method and application [P]. WO2019120235 A1 20190627.

[18] S. Bang, T. K. Quy Ha, C. Lee, W. Li, W. K. Oh and S. H. Shim (2016). Antiviral activities of compounds from aerial parts of Salvia plebeia R. Br, J. Ethnopharmacol, 192, 398-405.

[19] B. Pfundstein, S. K. El Desouky, W. E. Hull, R. Haubner, G. Erben and R. W. Owen, (2010). Polyphenolic compounds in the fruits of Egyptian medicinal plants (Terminalia bellerica, Terminalia chebula and Terminalia horrida): Characterization, quantitation and determination of antioxidant capacities, Phutochemistry 71(10), 1132-1148.

[20] B. M.Markaverich, R. R.Gregory, M. A. Alejandro, J. H. Clark and B. S. Middleditch (1988). Methyl phydroxyphenyllactate. an inhibitor of cell growth and proliferation and an endogenous ligand for nuclear type-ii binding sites, J. Biol. Chem. 263(15), 7203-7210.

[21] M. Nascimento, P. M. Galdino, I. F. Florentino, B. L. Sampaio, F. A. Vanderlinde, J. Paula and E.A. Costa (2011). Antinociceptive effect of Lafoensia pacari a. st.-hil. independent of anti-inflammatory activity of ellagic acid, J. Nat. Med. 65(3-4), 448-454.

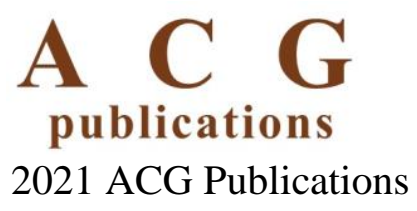

